\title{
A Study on the Reformation of Religion and Education in Dürer's Art Works
}

\author{
Jeong-Jae Lee \\ Namseoul University, Korea \\ chchlee@nsu.ac.kr
}

\begin{abstract}
The Reformation advocated the five pillars of Christianity, Five Solas, which first emerged during the Reformation. Sola Scriptura (Only the Bible), Solus Christus (Only Christ), Sola Gratia (Only Grace), Sola Fide (Only Faith), Soli Deo Gloria (Only God's Glory). The Reformationists Luther, Calvin and Zwingli opposed Catholic papacy through their reformism. The education reform was in The Reformation contents. The concept of modern public education began with reformism. They distinguished between truth and falsehood and said value and worthlessness. They borrowed the artistic talents of a painter like Dürer. This treatise examines the educational content of The Reformation through Durer's work.
\end{abstract}

Keywords: Christianity education, Reformation, Luther, Alfred dürer

\section{Introduction}

The education is an important process of human formation and a means of social transformation. R. S. Peters saw that education is a worthy activity or a movement of people in the form of thought and action. There are three criteria that are logically included as the concept of education. Namely, he said that have to meet the normative, cognitive, and procedural standards. It is the concept of socialization of education presented in E. Durkheim's <Education and Sociology $>$. He defined education as a systematic socialization for the younger generation [1][2][3][4].

I. Kant is important when talking about modern education in the West. For Kant, the education is an act of forming human beings humanly. He emphasizes moral and human aspects. On the other hand, E. Spranger focused on culture and knowledge. He saw relatively mature people pulling immature people from their natural state to their ideal state. It is said that is meaningful, concrete, and continuously affecting through cultural property. In other words, he saw education as a cultural function.

J. H. Pestalozzi was a pedagogist who had a social world view. He saw the education as a means of continuous reform in society. It emphasized the development of nation or state or social reform rather than conscious self or autonomous completion as an individual. O. Willman or J. Maritain saw the education from a theological and religious point of view. He saw the education as a realization of God's will.

In this way, the definition of education differs from scholar to scholar. But one thing in common is that it is a "human formation process". However, in the modern era, the

${ }^{1}$ Funding for this paper was provided by Namseoul university Article history:

Received (January 16, 2019), Review Result (March 7, 2019), Accepted (May 3, 2019) 
consciousness to release from individual awareness and authority began to sprout through the movement of Renaissance and Reformation [3].

\section{Religious pluralism and Christian education}

Today, society is in a pluralistic cultural environment for religion. Christianity has a conflicting relationship with existing religions and cultures [4]. What this situation tells us is that Christian education given by God can not be properly addressed to his tasks and missions. Thus, there is a need to identify the role of Christianity and its mission in the culture of religious pluralism.

\subsection{Relationship between Christianity and religion}

Karl Barth thoroughly distinguished between religion and faith. He saw that the revelation and true faith of Christianity meant that God came toward man. He emphasized that the Word of God and Jesus Christ must be accepted unconditionally. Karl Barth's "Word of God and acceptance of Jesus Christ unconditionally" is the starting point for the possibility of God's recognition in the revelatory premise. This refers to the exclusion of human effort [5]. D. Bonhoeffer who the pastor called for the mature and responsible behavior of the Christian faith. He pointed out that the values of Christian noble life were not practiced in real life. T. Tillich understood religion as the ultimate interest in human life. The question of the meaning, value, and essence of life stressed that God's revelation gives the answer. If Christianity fell into a Godless ideology, it would have lost its meaning as an education for humanity.

\subsection{Culture of religious plural society and mission of Christian education}

The education has the function of transferring culture. The transcendence of culture is accompanied by the role of religious tradition at the same time. The mission of Christian education is to have a goal in the formation of Christian social culture [6]. Christianity has to fulfill its responsibility to continue to expand and sustain. Christian culture is that the truth, which is the word of God, becomes the foundation and center of the social order. The justice, peace, and love of God will dominate and bring about the visible realization of the kingdom of God. It must do that Jesus Christ is confessed as the "Lord" of order and value. The individual, society, and the world mean a life that follows his teachings. In addition, to form a Christian cultural environment, it is necessary to bring about change of human perception, change of behavior and change of life for realization. To this end, the ministry to nurture and awaken human beings is a function of Christian education and a mission.

\section{16th century reformation and educational reform}

The historical and historical background in which the Reformation took place must be found in the process of the full change of European society in the Middle Ages [7]. The growth of the ruling powers, gradually growing and strengthening around the kingship, made the pope lose its foundations. Thus, the Reformation could be seen as a prelude to the strong criticism of the Catholic Church that had begun slowly in the Middle Ages and the fierce criticism of the Papacy.

The direct cause of the German Reformation was the indulgence that was carried out in 15141517. At that time, the Pontifical luxury was at its height. Pope Leo PP X needed enormous funds to reconstruct the Peter Temple. So the Archbishop of Mainz, Germany, approved the sale of the indulgences. In response, Luther contradicted the absurd doctrine of forgiveness and salvation coming from the Pope's indulgences. 
Luther (Martin Luther, 1483-1546), He posted the refutation for the Reformation on October 31,1517 , at the gate of the Church of Wittenberg. This was the beginning of his reformation. Luther again proclaimed the words of Scripture Romans 1:17. The salvation of man could be done only by the faith of the Bible and the individual, not by indulgence. He was told to pray for relief by faith rather than for pardon, so it can be said that the basic idea of the Reformation is based on faith and biblicalism. He wanted to escape from the autonomous, indirect beliefs that were possible only through churches and priests. He pursued a change to an autonomist and direct faith that could be communicated directly with God. Thus, the pontifical formalism collapsed and personal contentism emerged.

\subsection{Influence of reformation on education}

Luther translated the Bible into German and contributed to the popularization of education. The Reformation needed not only the people of the minority class, but also the general public to develop reason and to secure faith in God. Protestantism had allowed children to have a pleasant education as a result of their freedom of faith and their emphasis on humans themselves. Scientific truths were allowed. Therefore, education was focused on cultivating useful people in real society. This emphasis on the importance of home education had a great influence on Heinrich Pestalozzi (1746-1827) later.

Luther's educational philosophy was the mandatory schooling of children. He emphasized the national accountability of education. The schools should be operated as public institutions by the public expenses of public organizations. In other words, the establishment and maintenance of the school is not the responsibility of the church but the responsibility of the national government. This has laid the foundations of the public education system today. Among the ideas of Luther's Reformation, the most significant influence on education was the idea of "education should be given to all peoples".

The Reformation of Luther, Calvin and Zwingli was a movement that occurred at the time of the dismantlement of the feudal society and the contradiction of the Catholic Church at that time [8]. This reform movement was not just a religious reform. It was a social reform movement that spread throughout Europe and an education reform movement. Through this Reformation, human reason was awakened. So the normal education could spread [9].

\section{The art of dürer with religion and education reform}

The printmaking was the medium of art that made the greatest contribution to spreading and spreading the ideology of the Reformation. In the era of the Reformation, the medium of printmaking was very proliferative.

On the side of the Reformation, they mainly produced a theme that contrasted with the subject and sermon scenes showing the difference of Catholic and Protestant worship rituals [10]. Dürer also made a lot of indulgence sales scenes and accused the Pope of selling indulgences. The illustrations in the Catechism were also actively produced by prints. The printmaking had been produced with the intention of propaganda of political propaganda. In this paper, I will focus on the works of Alfred Dürer.

\subsection{Interpretation of dürer's printed works}

Dürer's "Self Portrait", which he painted in 1448 at the age of only 13 years old, reveals his genius. Jesus' arrest (1480) [Figure 1]. He had a profound understanding of the Bible and an 
excellent technique [11]. He overcame the medieval German tastes of tragedy and suffering, which had been dominant until then, in his own artistry.

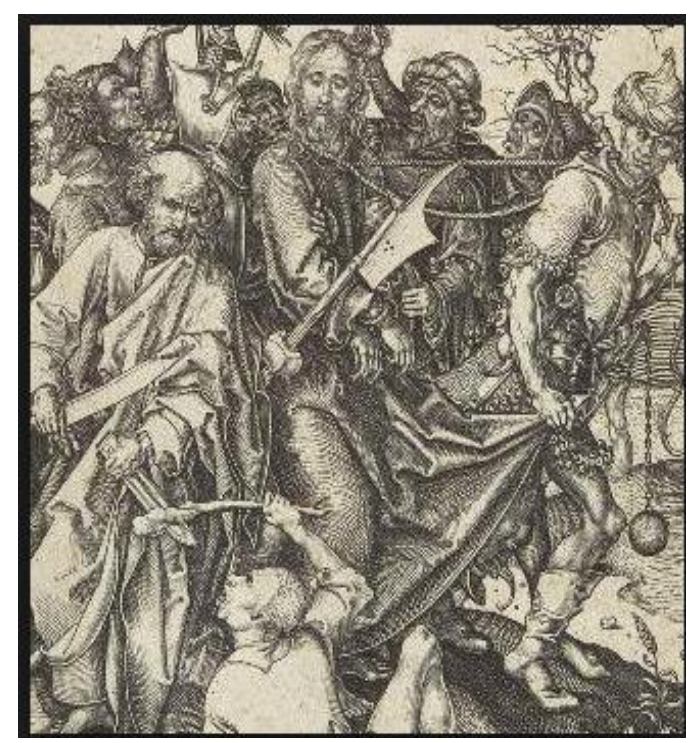

Figure 1. Jesus' arrest (1480)

Dürer was influenced by famous Italian artists, but it was not entirely his world. In many areas, Dürer is obviously the founder of the Nordic Renaissance. But most of all, he lived in the Reformation era, the Peasant War, the Black Death and the escalating eschatological crisis consciousness. In this period of social disturbance, Dürer established a Renaissance style in Northern Europe with his own perspective. He was a great artist [12].

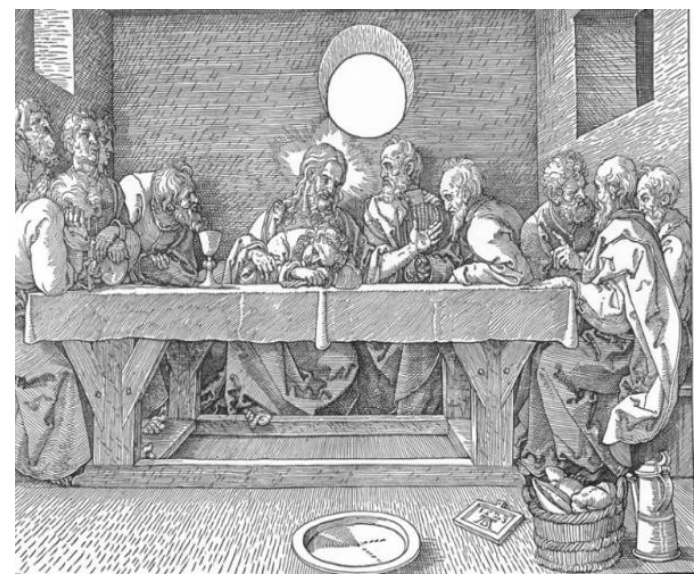

Figure 2. Previously covered with lamb

In some of Düre's works, his sympathy for the Reformation can be found. There was a print of the eleven apostles are sitting at the table centered on Christ. Dürer seems to have focused more on the scene where Christ teaches the new gospel. The background is also not a former Gothic cathedral building. In the flat rectangular building of early Christian style, this story is said. The Apostles are described as a community of Christ in the early church. The empty dish in the foreground was previously covered with lamb [Figure 2]. Rather than emphasizing the 
sacrifice of Christ, it emphasizes that the Church sacrament meeting is a ritual commemorating Christ. This shows that the Reformed Church has an accident different from Catholicism.

\subsection{Educational interpretation of dürer's paintings}

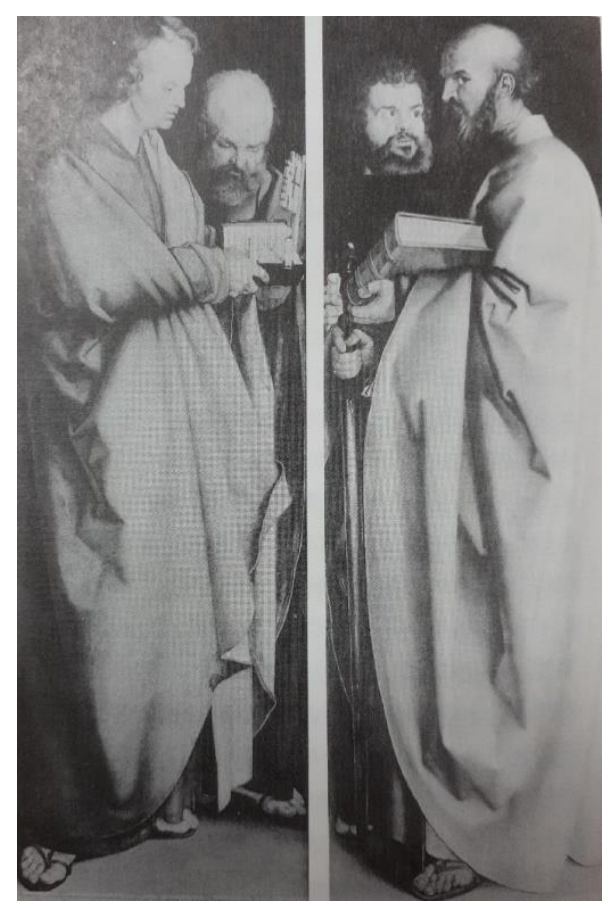

Figure 3. The four apostles (1526)

The Four Apostles (1526) [Figure 3] depicts the apostles John, Peter, Mark, and Paul. In this work, the rank order of the apostles that had been consciously accepted was changed. Dürer expresses sympathy for the Reformation. Since Peter was described as having received the keys of the kingdom of heaven as Saint Peter, he was equated with the pope. In this work, however, John and Paul, not Peter, are located in the most prominent place. They placed Peter and Mark in the middle of them. John was the apostle Luther liked most. Paul was esteemed as the spiritual father of the Protestant because of his courage.

The arrangement of these apostles demonstrates that Dürer fully respected to Luther. Inscriptions at the bottom of the picture also include 1 John 4: 1-2, 2 Peter 2: 1-2, 2 Timothy 3 : 1, and Mark 12:38. These are warnings about false teachers, prophets, heresies, scribes, and outsiders. At that time, the problems of the Catholic Church are attacked again by Dürer [8]

\section{Conclusion}

Dürer has created an enormous social change issue through the medium of printmaking. At that time, many German farmers did not know how to read and write [13]. So the Germans and Europeans who saw Dürer's print works could accept it as a shocking event. They saw the distorted Catholic problem of the devastating religious content. That power made the flame of the Reformation more visible. Dürer was a social educator to the church and the public with the art medium. In addition, Dürer expressed the apostleship of Christ again what distorted the image of the gospel due to the authority of the pope. It is a work that made social education function to see the image of the church that has continued since the old Renaissance. The art of 
Dürer with the Reformation was a very important historical event that made society change and restores the right faith.

\section{References}

[1] Benjamin Wiker, “The Reformation 500 years later," Regnery History, United States, (2017)

[2] Caneron A. Mackenzie, "The Reformation," Concordia Publishing, (2006)

[3] Daniel J. Treier, "The Beauty of God," InterVarsity Press, (2007)

[4] David F. Wells, "Reformed Theology in America," Wm. B. Eerdmans Publishing Company, (2017)

[5] Richard Viladesau, Theological Aesthetics, Oxford University Press, Usa (1999)

[6] Richard Viladesau, "Theological and Art," Paulist Press, (2000)

[7] Erwin Panofsky, “Albrecht Dürer 1.2," HAZAN; HAZAN edition, (1943)

[8] Martin Baily, "Dürer,” Phaidon Inc Ltd, (1995)

[9] Michael Horton, Where in the world is the church?, P \& R Publishing, (1995)

[10] Michael G. Bayler, “The German Regormation and the Peaasants'war,” Bedford/St. Martin's, 1 edition, (2010)

[11] Paul Louis Metzyer, "The word of Christ and the World of Culture," Wipf and Stock Publishers, (2003)

[12] Randall C. Zachman, "Image and word in the Theology of John Calvin," University of Notre Dame Press, (2007)

[13] Wiliam A. Dyrness, “Reformed Theology and Visual Culture," Cambridge University Press, (2004)

\section{Authors}

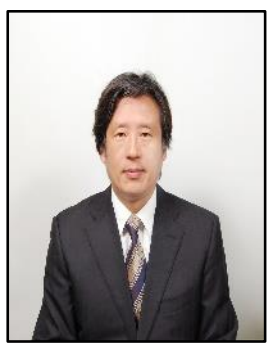

\section{Jeong-Jae Lee}

Ph.D in Art

Professor of Namseoul Univ. Korea 